\title{
Collaborative Writing in Group Assignments in an EFL/ESL Classroom
}

\author{
Ahmed Ali Saleh Al Ajmi ${ }^{1} \&$ Holi Ibrahim Holi $\mathrm{Ali}^{2}$ \\ ${ }^{1}$ Department of English Language \& Literature (DELL), Rustaq College of Applied Sciences, Oman \\ ${ }^{2}$ School of Education \& Professional Development, University of Huddersfield, UK \\ Correspondence: Ahmed Ali Saleh Al Ajmi, Rustaq College of Applied Sciences, Rustaq, P.O. Box: 10, PC 329, \\ Oman. Tel: 968-2687-5244. E-mail: ahmed.ali.alajmi@gmail.com
}

Received: June 13, 2014

Accepted: July 7, 2014

Online Published: July 16, 2014

doi:10.5430/elr.v3n2p1

URL: http://dx.doi.org/10.5430/elr.v3n2p1

\begin{abstract}
The importance of collaborative writing (CW) is well attested in English Language Teaching (ELT). This study attempts to explore English as Foreign Language (EFL) teachers' and students' views, perceptions and experiences with $\mathrm{CW}$ and to find ways to improve this type of writing practice. Quantitative and qualitative methodologies were employed to collect the data. To address the issues in the study, a questionnaire was distributed to 64 EFL students at a public college in Oman and five teachers were interviewed. The findings show that the vast majority of teachers and students had positive views about the current $\mathrm{CW}$ practices, which concurs with the findings of previous research. Further, the study indicated that both students and teachers can play a significant role in improving CW practice by following certain strategies, such as those involving clarifying $\mathrm{CW}$ task learning outcomes, fair assessment, monitoring, solving CW group conflicts, $\mathrm{CW}$ group management and clear division of $\mathrm{CW}$ group work. Based on the teachers' and students' views, and the findings from the literature, some suggestions for improving $\mathrm{CW}$ are proposed which may help to enhance $\mathrm{CW}$ practice.
\end{abstract}

Keywords: Collaborative writing, EFL Context, Students' perceptions, Teachers' perceptions

\section{Introduction}

\subsection{Statement of the Problem}

The importance of collaborative writing is well-attested in second language learning and teaching. Shehadeh (2011) points out that collaborative work has become popular worldwide in language classrooms over the last two decades. Therefore, many language teachers and researchers are attracted by the idea of collaboration in second language learning ( $\mathrm{Li} \& \mathrm{Zhu}, 2013)$. The positive outcomes of collaborative writing $(\mathrm{CW})$ are not restricted to the learners' current language learning, and its benefits it can go beyond simple language classroom collaboration. Wigglesworth and Storch (2009) highlight how collaborative writing can provide learners with the experience they need for their future education or for the workplace. Many research projects conducted on $\mathrm{CW}$ emphasise its significance in language learning (Batstone, 2010; Ellis, 2003; Garcia Mayo, 2007; Lantolf, 2000; Shehadeh \& Coombe, 2010); that is, CW can mediate the construction of linguistic knowledge (Swain, 2010), it helps students to recognize language structures (Kuiken \&Vedder, 2002b) and it enables students to develop reflective thinking which results in greater awareness and understanding of the intended audience (Bruffee, 1993). Given this position, it can be argued that CW is effective for language learners (Mutwarasibo, 2013; Razmjoo \& Hoomanfard, 2012). Moreover, it is of utmost importance to emphasise that $\mathrm{CW}$ tasks should be well-designed and carefully monitored to help learners to work collaboratively (Storch, 2011). The Department of English Language and Literature (DELL) at Rustaq College of Applied Sciences applies CW as students do most of their assignments collaboratively. Yet, the DELL needs to examine this practice closely due to some issues such as students' repeated complaints about the challenges they face while doing $\mathrm{CW}$ projects including lack of time, unproductive group members, unfair assessment, and lack of group work culture. To address this issue, the present study attempts to explore teachers and students views about the use of $\mathrm{CW}$, the problems students face in $\mathrm{CW}$, the causes of such problems and how $\mathrm{CW}$ can be promoted among students.

\subsection{Objectives of the Study}

The following are the objectives of the study: (1) to explore teachers' and students' views about the use of CW; (2) to investigate the problems the students face in CW and explore the causes of these problems; and (3) to elicit teachers' and students' views on how to promote $\mathrm{CW}$ practice in DELL. 


\subsection{Research Questions}

1) What are the students' views about the use of CW?

2) What are the problems the students face in $\mathrm{CW} \&$ what are the possible reasons behind CW problems?

3) How can CW practice be promoted among students?

\subsection{Significance of the Study}

CW is believed to have many benefits for second language learners. McDonough (2004), for example, points out that $\mathrm{CW}$ provides students with pedagogical gains in their second language learning. That is, "Learners first collaboratively construct knowledge as a joint activity, and then transform it into a mental one through the processes of approximation and internalisation" (Shehadeh, 2011, p. 297). The current study is significant because it attempts to explore teachers and students views about $\mathrm{CW}$, problems they face, and the reasons behind these problems. The study proposes pedagogical guidance for improving CW practice that would help the DELL enhance its practices by using the most suitable procedures. This is the first study of its type in this particular context to be devoted to this type of analysis of CW.

\subsection{Context of the Study}

This study was conducted at the DELL at Rustaq College of Applied Sciences, Oman. Students in the DELL are assessed in many different ways including CW tasks in the form of assignments or research projects, which usually have a weighting of around $20 \%$ of the overall assessment. Biria and Jafari (2013) assert that "Writing is no longer an individual activity but an integrative process through which social abilities of the learners are reinforced" (p. 164). The DELL thus needs to closely examine its $\mathrm{CW}$ practice to ensure that such benefits of $\mathrm{CW}$ are obtained.

\section{Theoretical Aspects}

\subsection{Significance of Collaborative Work for L2 Learning}

Nowadays, collaborative work can be seen almost in every language classroom because it has gained in popularity worldwide over about the last 20 years (Shehadeh, 2011). Many researchers point out that collaborative work is significant to language learning and teaching (Batstone, 2010; Bygate, Skehan, \& Swain, 2001; Ellis, 2003; Garcia Mayo, 2007; Lantolf, 2000; Shehadeh \& Coombe, 2010; Van den Branden, Bygate, \&Norris, 2009). For example, using group work in the language classroom is believed to motivate students to learn, enhance students' self-esteem and self-confidence, and lead them to success (Hillyard, Gillespie, \& Littig, 2010). Some researchers state that, by working together, students establish life-long values; namely, they learn how to listen to other people carefully, question the information they get, respect the viewpoints of others and practise mutual collaboration and share knowledge (Hammond, Bithell, Jones \& Bidgood, 2010). Johnson, Johnson, and Smith (2007) assert that learning how to collaborate in groups is considered to be a form of knowledge.

\subsection{Writing as a Social Act}

According to Yang (2014, p. 75), "Writing is viewed as a social act" as students' collaborative work is underpinned by sociocultural theory (Fung, 2006) and social constructivist theory (Fung, 2010; Shehadeh, 2011). Sociocultural theory, according to Fung (2006), asserts that the learning process is shaped when individuals work together on a meaningful activity. That is, learning is contextualised because this theory focuses on the social, cultural and historical contexts. Lightbown and Spada (2006) point out that this theory shows cognitive development as a result of social interactions. For example, the development of language, which is seen as a "cognitive development", takes place due to the social interactions individuals carry out in their daily lives. That is, language such as writing mediates thinking (Lightbown \& Spada, 2006).

Social constructivist theory claims that social interactions are prerequisite for cognitive development (Bruffee, 1986; Vygotsky, 1978). Learning, including writing, is a social activity and it is the outcome of the internalisation of ideas in the sociocultural environment. As the development of man is a social activity (Vygotsky, 1978), the cognitive and linguistic development of children appears through social interaction as they obtain scaffolding from the older members of society (Shehadeh, 2011). Researchers state that scaffolding can be found in L2 classes (Alegria de la Colina \&Garcia Mayo, 2007; Donato, 1994; Kim, 2008; Kuiken \& Vedder, 2002a; Nassaji \& Tian, 2010; Storch, 2002; Swain, 1998, 2000, 2006, 2010; Swain \& Lapkin, 1998, 2001, 2002; Swain et al., 2009). For example, students obtain scaffolding from their teachers and/or their peers while doing group work such as CW tasks. That is, "This interaction may happen between course instructors and students or among students through pair and group work" (Mutwarasibo, 2013, p. 2). Students, therefore, should take an active role and collaborate throughout the writing process (Daiute, 1986) as this reflects shared responsibility for text production, establishes a sense of ownership, and 
ensures that all group members take part in working out the content, structure and language of the written text (Storch, 2005). The current study, therefore, centres on problems the students face while doing CW tasks such as having passive group members and lack of a good group work culture. The study also explores the causes of these problems in order to enhance $\mathrm{CW}$ practice in the DELL.

\section{$2.3 \mathrm{CW}$ in Second Language Writing}

Manchon (2011) distinguishes between two dimensions of writing: leaning to write and writing to learn. Through the first dimension, students express themselves by writing in L2. Hyland (2011) points out that there are three main approaches to understanding learning to write and how it can contribute to L2 classroom practice. The first approach focuses on the writer and the cognitive process; that is, learners are provided with expert-level practices to help them produce a text. The second approach looks at the products of writing: one of these products is "text", which refers to students applying the rules of writing; the other product is "discourse", which means going beyond the surface structure to realise our goals in particular situations. The third approach focuses on the role that readers play in writing; that is, as Hyland (2011, p. 26) states: "The idea of context beyond the local writing situation to the context of use and what writers do to address the reader" in the second dimension of writing, learners focus on the other functions of writing, such as the process of writing in L2 itself, and engaging with the various tasks and activities that learners undertake in their L2 writing. Hirvela (2011, p. 37) defines writing to learn as "how to use writing to mediate or enrich learning in another language". Emig (1977) points out that writing to learn helps students to learn about the different courses they study in school. Herrington (1981) asserts that the rationale behind writing assignments is to learn. One might wonder about how writing enhances students' learning, not only about the writing process itself, but also expanding their knowledge about the content. Newell (1998) confirms that writing helps learners to "know" and to "do" at the same time; for example, students gain knowledge by exploring and re-examining what they intend to write about and then reproduce the knowledge they have gained by writing it down. These two distinguishing dimensions of writing play a significant role in promoting learning: learners can develop their content knowledge (Hirvela, 2011; Swain, 2001) as well as improve their knowledge about language (Williams, 2012). Thus, when students write collaboratively, they learn a lot through the process of 'languaging' and language-related episodes.

"Languaging" is a term used to describe what happens during learners' interaction with each other when they work collaboratively. It refers to "The process of making meaning and shaping knowledge and experience through language" (Swain, 2006, p. 98). This definition leads us to understand that languaging is not only a medium for developing meaning, but that it also plays a role in making meaning itself. Swain (2006), for example, points out that individuals use language as a mediator for cognition or thinking. With regard to developing one's experience through language, some researchers have stated that speaking and writing help to enhance people's experience. Vygotsky (1978), Barnes (1992) and Wells (1999) point out that spoken and written discourse can serve as a vehicle for developing and reshaping one's experience.

When learners write collaboratively, they benefit from languaging as they have the chance to interact with each other over different aspects of writing (Storch \& Wigglesworth, 2007), and they also have opportunities to learn and explore the language they are using through discussion about it (Wigglesworth \& Storch, 2012). Shehadeh (2011) further explains what happens when students interact in collaborative writing tasks. He states that "Learners first collaboratively construct knowledge as a joint activity, and then transform it into a mental one through the processes of approximation and internalisation" (p. 297). Therefore, languaging in the context of collaborative writing is about students' discussion of how to solve problems related to language use (Swain, 2006, 2010) as they collectively construct a deeper understanding of language (Swain, 2006). Collaborative activities encourage learners to engage with language at the "conscious" level (Wigglesworth \& Storch, 2012, p. 365), and that is why Swain (2000, p. 51) acknowledges the "conscious focus on language form".

Researchers have described the discussions that learners have about language when they work collaboratively as Language-Related Episodes (LREs). LREs are used as a measurement and analysis tool in such discussions (Amirkhiz, Abu Baker, Abd. Samad, Baki, \& Mahmoudi, 2013). Swain and Lapkin (2001) define LREs as segments in the learners' dialogues where they have discussions about language. Such deliberation about language can be about the choice of lexical categories and the use of accurate grammar, or it can focus on the mechanics and so on. For example, if learners are not sure about whether to use the present perfect or the present simple tense in one of the sentences of their CW tasks, they simply share their knowledge about this issue for the sake of making a clear decision about correct use. Wigglesworth and Storch (2012) indicate that when learners consider writing as a social activity and jointly contribute to the writing process, this will result in enhanced learning, as they learn through 
discussion and scaffolding. However, it is very important to consider the fact that, in languaging, students with a low L2 proficiency level are bound to have a negative effect because the LREs may be affected in terms of quality and quantity (Storch, 2011).

A number of studies have been conducted on LREs in order to find out what types of LREs learners produce while languaging and what affects how they are produced. Table 1 below summarises a number of studies and their findings conducted over the last two decades.

Table 1. Types of LREs produced by students in different studies conducted over two decades

\begin{tabular}{ll}
\hline Study & \multicolumn{1}{c}{ LREs produced by learners } \\
\hline Nelson \& Murphy (1992) & $\begin{array}{l}\text { Word order, rhetorical organisation, cohesive devices, lexical } \\
\text { ties, usage and style } \\
\text { Lockhart \& Ng (1995) }\end{array}$ \\
Ideational aspects
\end{tabular}

Williams $(1999,2001)$

Leeser (2004)

Storch (2005)

De la Colina \& Garcı'aMayo (2007)

Storch \& Wigglesworth (2007)

Watanabe \& Swain (2007)

Aldosari (2008)

Kim \&McDonough (2008)

Amirkhiz et al. (2013)
Lexical items more than grammatical items. More metatalk found among more proficient learners

Lexical and grammar-based

Idea generation and language issues

Text reconstruction task elicited more LREs than jigsaw and dictogloss techniques

More lexical LREs than grammar-focused LREs

More LREs produced when interaction is with high level interlocutors.

Tasks of a meaning-oriented nature elicited learners' attention to lexis, while less meaning-oriented tasks produced grammar-based LREs

The more advanced the interlocutors, the higher the number of LREs produced. Lexical LREs were the majority

Form-oriented LREs (FO-LREs), Lexis-oriented LREs (LO-LRE) and Mechanics-oriented LREs (Mo-LREs).

Table 1 reveals that the LREs produced by learners differ from one study to another. In fact, there are four main factors that affect the LREs that students produce. The first factor is the type of collaborative task given to the students (Aldosari, 2008; Storch, 1997). The task type draws students' attention to language in different ways (De la Colina \& Garc1'aMayo, 2007). For example, Storch and Wigglesworth (2007) show that the meaning-focused nature of the tasks used in their study made the students pay greater attention to lexical choices than to grammar. The second factor is the students' proficiency level, as the proficiency level can affect the quality and quantity of the LREs (Amirkhiz et al., 2013). For example, research shows that the higher the proficiency level of the students, the greater the amount of LREs they produce (Kim \& McDonough, 2008; Watanabe \& Swain, 2007; Williams, 1999, 2001). Leeser (2004) points out that streaming students according to their proficiency level affects the amount of LREs they produce, the types of LREs they focus on and the outcome of the LREs. For example, the study conducted by Storch and Wigglesworth (2007) shows that the students focused on lexical choices as a result of their advanced 
proficiency level. The third factor affecting the LREs that students produce is the relationship between the students in the CW group. Aldosari (2008) claims that the relationships that students form could have a greater effect on LREs than the students' proficiency level. Finally, a recent study conducted by Amirkhiz et al. (2013) shows that students of different cultural and learning backgrounds produce different LREs. They point out that "Learners possessing a similar level of proficiency, but with different cultural background and English learning histories could come up with totally discrepant sets of LREs" (p. 477). Considering the importance of the LREs students produce during their CW, the current study considers the factors described above that influence the production of LREs by exploring teachers' and students' views about what problems students face in CW such as proficiency level, cultural and disciplinary backgrounds, relationship among students and the writing task itself.

\subsection{Previous Studies on Learners' Attitudes toward CW}

A number of studies have been conducted in EFL and/ or ESL contexts to explore students' attitudes towards CW undertaken either in pairs or small groups. Some of these studies explored students' perceptions of CW by employing actual writing tasks and some designed other special tasks for the purpose of the studies. Research reports that students have positive attitudes about CW (Dobao \& Blum, 2013; Elola \& Oskoz, 2010; Ewald, 2005; McDonough \& Sunitham, 2009; Shehadeh, 2011; Storch, 2005; Zeng \& Takatsuka, 2009).

In a study conducted by Storch (2005) on 23 adult ESL students in an Australian university, 18 students were asked to do a writing task in pairs while five students did this task individually. The students were interviewed afterwards: 16 out of the 18 students, who did the task in pairs expressed very positive attitudes to writing in pairs as it helped them pool their resources, observe each other and learn how to express the same ideas in different ways. However, it is worth highlighting that those five students out of those who expressed a positive attitude did so with some reservation because they lacked confidence in their language skills and were concerned about criticising others (Storch, 2005). In Storch's study, two students said that writing is an individual activity and that paired work is good for oral activities.

A 16-week quasi-experimental study conducted by Shehadeh (2011) in an EFL context aimed to explore the effectiveness of CW and students' perceptions of it. Twenty students were asked to write individually while 18 students wrote in pairs. Shehadeh (2011, p. 286) points out that the "Results of the study showed that CW had an overall significant effect on students' L2 writing". That is, most of the students expressed a positive attitude toward $\mathrm{CW}$ and they enjoyed it, although they were novices at such an experience. They also acknowledged that $\mathrm{CW}$ was beneficial to them (see Shehadeh, 2011, p. 296) as it provided them with opportunities to discuss and plan their writing, generate and pool ideas, create texts jointly, give immediate peer feedback and polish up their text. Further, the students reported that $\mathrm{CW}$ helped them have self-confidence and improved their speaking abilities.

A recent study by Dobao and Blum (2013) looked at the attitudes of 55 Spanish EFL learners towards writing in pairs and small groups. The students were given a written task to complete as a part of their classroom activities: 27 of them did the writing task in groups of four while 28 did it in pairs. Generally, the students were positive about their CW experience, except four students who said they "would have preferred to write individually" (Dobao \& Blum, 2013, p. 365). Those who wrote in pairs reported that such experience is good because it provides them with more chances to take an active part in the writing process. The students who wrote in groups of four highlighted that this experience was a good opportunity to broaden their horizons in terms of sharing ideas and knowledge. They also reported that this was a good chance to develop their language including, for example, their understanding of the grammatical and lexical aspects of language.

Based on such studies, the DELL therefore should consider the students' perceptions and attitudes towards CW when they do their writing assignments collaboratively. That is, the DELL should examine the benefits of CW practice in order that these can be retained and reinforced. Further, the DELL should also pinpoint the problems and challenges the students experience with $\mathrm{CW}$ in order to address these problems. Accordingly, the current study is focused on students' and teachers' perceptions of the current CW practice in the DELL.

\subsection{Role of Teachers and Students in $\mathrm{CW}$}

Some teachers seem unwilling to perform $\mathrm{CW}$ in their L2 classes as they have been reluctant to integrate group work methods into their classrooms (see Granström, 2006; Hensvold, cited in Mutwarasibo, 2013). This reluctance appears to be triggered by the negative behaviour or attitudes that some students have when they write collaboratively. This because their avoidance and the complaints students make regarding group work. Although a number of studies show that students' overall impression of CW is very positive, there are some students in such studies who view writing as merely an individual activity (Storch, 2005). This lack of enthusiasm for CW could be for two reasons: one is that 
students do not have enough confidence in other group members' language skills; the second reason is the fear that the group members will contradict each other while working on their writing task (Mutwarasibo, 2013; Storch, 2005). Some researchers also point out that students who refused to take part in CW tasks attributed this to the existence of passive group members (Dobao, 2012) who prefer to depend on others to do all the writing work for them. Such group members are also called passengers, bystanders, free-loaders and free-riders (Bourner, Hughes \& Bourner, 2001; Davies, 2009; Race, 2010). Millis and Cottel (1998) also call these unproductive group members "Hitchhikers". Such members make the active group members unwilling to take part in CW tasks as they feel it is unfair that they should do all the writing work while at the end the unproductive members still get marks although they have contributed nothing to the written product. It seems, therefore, that students do play a role in encouraging each other and their teachers regarding whether or not to adopt CW.

Some teachers who apply $\mathrm{CW}$ in their classes think that their role in $\mathrm{CW}$ is not that important because they assume that their students know how to work in groups (Griffiths, 2009). In fact, such an assumption is not always true: some researchers point out that, in order to make $\mathrm{CW}$ practice a positive, enjoyable and successful experience, teachers should support their students (Cavanagh, 2011; Leach \& Zepke, 2011 Wingate, Andon, \& Cogo, 2011). Researchers also point out that there are some necessary prerequisites for group work which should be made available to them (Dobao, 2012; Hammar Chiriac, 2011). One of these prerequisites is training students how to plan and practise group work (Fawcett \&Garton, 2005; Gillies, 2008). More specifically, the teacher's role in group work is being a guide and facilitator (Mutwarasibo, 2013). That is, teachers should give clear instructions for the group work, set a deadline for the students to submit their group work, and ask students to present their final work to the whole class (Hensvold, cited in Mutwarasibo, 2013). Some teachers in the DELL ask their students to present the final product of their CW to the whole class as this, according to Race (2010), helps students learn from each other's work. For example, students sometimes write research projects on the same topic, but they approach it in different ways in terms of research methodology, research questions, data analysis and their conclusions. Such practice enriches students' learning. Shimazoe and Aldrich (2010) indicate that teachers should coordinate, guide, monitor, set frames and encourage students to interact with each other in group work. Griffiths (2009) adds two important roles for teachers in group work: one is to help students understand the nature and purpose of the group work they are going to conduct; the other role is to clearly set out the learning outcomes of the group work and help students understand them.

Therefore, it is of utmost importance to understand the roles of both students and their teachers in CW for the sake of improving such practice. In light of this, the current study tries to find out how both teachers and students in the DELL can enhance CW practice by exploring students' views on how they think they can improve CW practice and what they expect their teachers to do to help them have effective CW practice in an EFL classroom.

\section{Research Methodology}

The study design is a mixed method one which aimed to investigate the problems and challenges in $\mathrm{CW}$ in a public college. The study sought to elicit teachers' and students' views about current $\mathrm{CW}$ practices, what problems the students face when they write collaboratively and the teachers' and students' views on how CW instruction in the DELL can be improved. A questionnaire was designed to collect data from 64 EFL students and five EFL teachers were interviewed.

The questionnaire contained six parts: the first four parts consisted of a three-point Likert scales with responses ranging from agree to disagree, and the last two parts comprised open-ended questions. The rationale behind the open-ended parts of the questionnaire was to generate qualitative data to support the quantitative data produced by the first four parts of the questionnaire. Dörnyei and Taguchi (2010) point out that the inclusion of open-ended questions results in greater richness of the responses and help to identify previously unanticipated issues. The questionnaire was standardized through expert validation, and then it was reworded and any irrelevant items were removed. The internal consistency reliability as measured by the Cronbach alpha coefficient was found to be .68. This value is very close to the reliability coefficient of .70 which is recommended in most social science research contexts (see Dörnyei\& Taguchi, 2010; Yockey, 2011). As teachers play a significant role in CW instruction, five EFL teachers were interviewed. The teachers' interview contained four main questions. The other participants in this study were 64 EFL Omani students in the DELL who had spent 12 years studying English Language as one of their main courses in the public school. The EFL teachers interviewed were national and international teachers in the DELL who have experience in teaching writing in the EFL context. 


\section{Results and Discussion}

The current study attempted to explore teachers' and students' views about CW practice, what challenges the students face in $\mathrm{CW}$, what causes these challenges, and how these challenges can be overcome. The findings are presented and discussed in the form of both descriptive statistics (Tables 2-5) and graphs (Figures 1-4). A summary of the main themes elicited from the qualitative data is presented in Appendix A.

Table 2. Students' views about CW Practices

\begin{tabular}{llll}
\hline Questionnaire Item & M & SD & N \\
\hline 1. Motivates students to write & 1.28 & .576 & 64 \\
2. Saves students' time & 1.39 & .610 & 63 \\
3. Results in good pieces of writing & 1.43 & .562 & 61 \\
4. Helps students meet the deadlines of their projects & 1.49 & .642 & 64 \\
5. Encourages students to share their talents and experiences & 1.23 & .333 & 64 \\
\hline
\end{tabular}

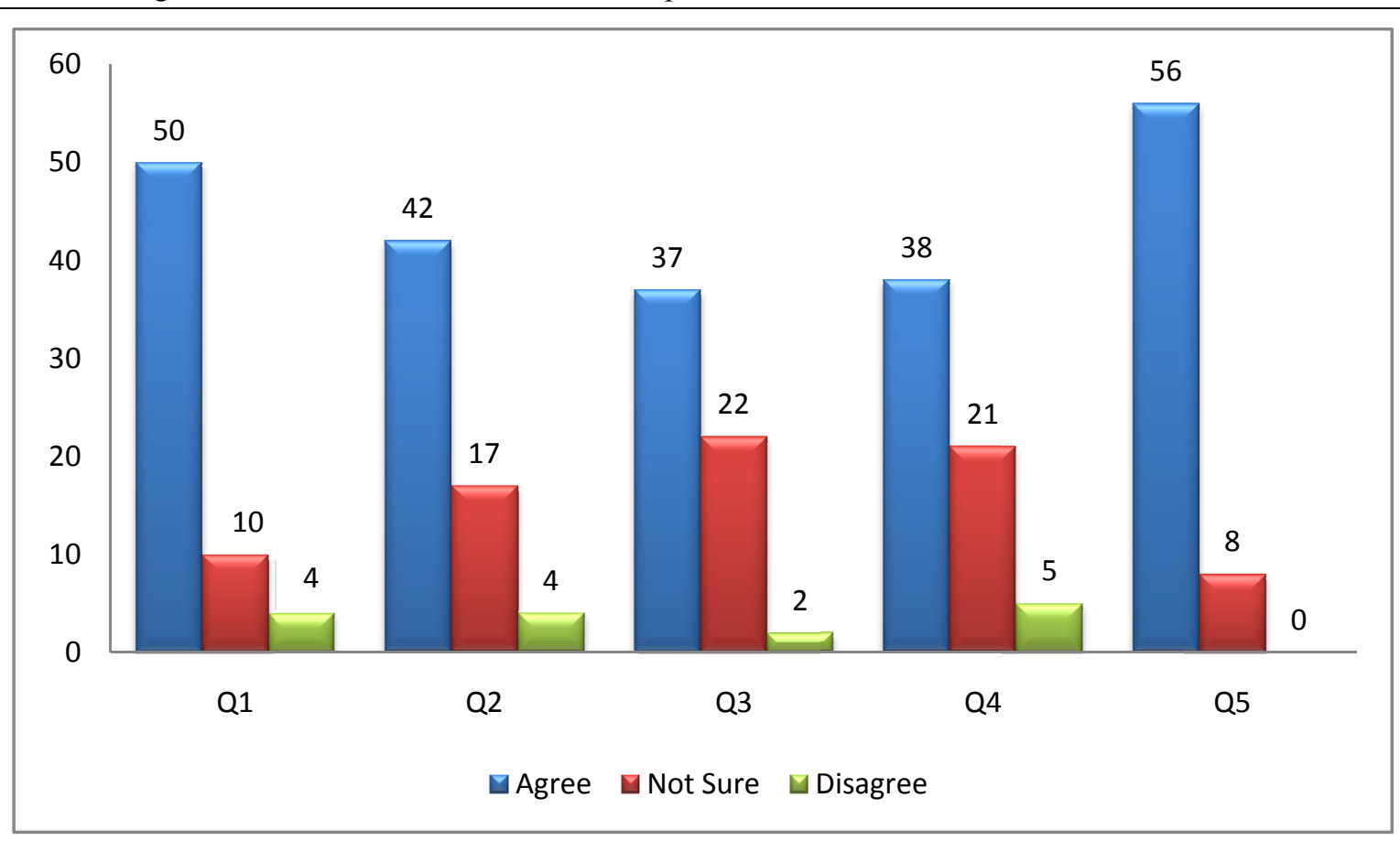

Figure 1. Students' views about CW practices

Table 2 and Figure 1 show students' views about the CW practice they had experienced in the DELL. In response to Question 1 about whether $\mathrm{CW}$ motivates students to write or not, 50 students agreed that $\mathrm{CW}$ writing motivates them to write, 10 students were not sure and four disagreed. This is supported by Hillyard et al. (2010) who believe that working in groups, such as in CW, motivates students to learn. Regarding Question 2, 42 students agreed that CW saves them time, while 17 students were not sure about this and four disagreed. While students underlined the importance of $\mathrm{CW}$ in saving time, the qualitative data show that six students were mainly concerned about time when they did not study the same courses: "working in groups takes a long time because students are not free at the same time to do the project". This concern could be overcome if students worked on time management, as five students expressed. For example, one student suggested "specifying time for each stage" and another supported this by saying "organise your work and choose the right time to do the project when all the members of the group are free". This is line with Yang's (2014) claim that group harmony facilitates CW. In their response to Question 3 on whether CW results in good pieces of writing, 37 students agreed, 22 were not sure and only two disagreed. Wigglesworth and Storch (2012) point out that, when students write collaboratively, they practise mutual learning which, in turn, results in a better writing product. For Question 4, which looked at whether CW helps students meet the deadlines for their projects, 38 participants agreed with the statement, 21 were not sure and five disagreed. Only one student expressed the view that "some of the students don't do their work at the time that the team determined before". In this regard, 
three students asked for adequate time to do their $\mathrm{CW}$ projects and one of them expressed the view that the role of teachers is "To inform the students about the project and the procedure for doing it at the beginning of the course, so they have enough time to work better together". In response to Question 5, 56 students agreed that CW encourages students to share their talents and experiences, and eight students were not sure about this statement. One of the teachers said that "writing could be done collaboratively since students can exchange ideas while passing through writing stages". This view is supported in literature as students share the knowledge they have about the different aspects of the task (Hammond et al., 2010) such as discussing LREs (Swain \& Lapkin, 2001) in which the students share what they know about the language issues they face in CW. Overall, the five teachers interviewed expressed their support for $\mathrm{CW}$. One of them reported: "I do strongly support collaborative activities in the writing classes as well as giving collaborative assignments because each of the students can bring useful input into the assignment, that is, they can peer teach and easily achieve fruitful results/ outcomes". Another teacher said: "I support this. Students can learn from their peers". A third teacher expressed his support by saying: "Yes, because learners can share their knowledge and learn from each other and fill the gaps in each other's knowledge."

Table 3. Causes of Problems in CW Practices

\begin{tabular}{llll}
\hline Questionnaire Item & M & SD & N \\
\hline 6. Language proficiency level & 1.55 & .641 & 64 \\
7. Personality & 1.33 & .619 & 64 \\
8. Cultural background & 1.63 & .678 & 64 \\
9. Disciplinary background (i.e. studied in different schools before coming & 1.83 & .747 & 64 \\
$\quad$ to college) & & & \\
10. Students' understanding of the writing task itself & 1.50 & .667 & 64 \\
\hline
\end{tabular}

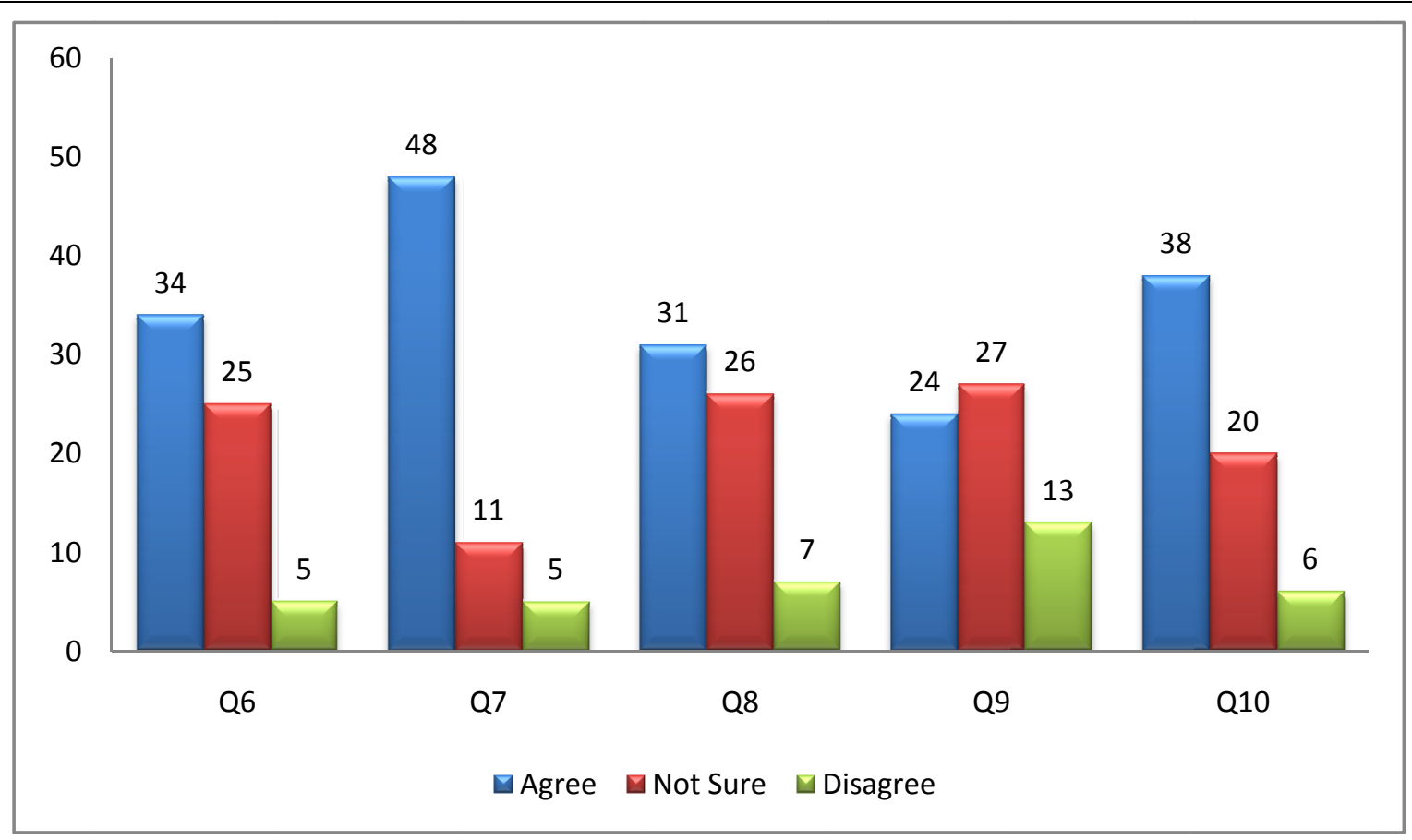

Figure 2. Causes of conflicts between students in CW

The reasons behind the conflicts that occur among CW group members are illustrated in Table 3 and Figure 2 . Regarding Question 6, which considers whether or not students' proficiency levels result in conflicts, 34 students agreed, 25 were not sure and five disagreed with this statement. Six students highlighted that language level is one of the challenges they face in CW. For example, one student expressed this by saying that conflicts result from "students' level, as those who are at a low level will rely on those who are at a higher level". These agree with Storch (2011) who indicates that students of low proficiency level could have a negative effect on the quality and quantity of LREs the students produce in CW. Regarding Question 7, the vast majority (48) agreed that personality is considered 
one of the causes of conflict among students, while 11 and five students respectively were not sure or disagreed. Ten students said that personality could lead to conflicts in opinions; for example, as one student put it: "students may have clashes in their opinions and over ideas to be included in the project". One teacher supported this: "Students might not agree about sub-ideas of the topics that will lead them not to take part in the writing process". A student said that it was "difficult to reach an understanding between team members at one point". Another student went further by saying that "people don't obey the rules and they conflict to agree for leadership". Three students suggested that "everyone should be honest and serious in their writing". On the effect of students' cultural background on the conflicts (Question 8), 31 students agreed, 26 students were not sure while seven disagreed. Regarding Question 9, 27 students were not sure about whether their disciplinary background could be one of the causes of conflicts, but 24 agreed that this was the case and 13 disagreed. This, to some extent, agrees with Amirkhiz et al. (2013) who states that students who come from different cultural and learning backgrounds produce different LREs and this, in turn, may cause conflict among students working on the same CW task. Thirty-eight students agreed, 20 were not sure, and six disagreed in Question 10, which was about whether students' understanding of the writing task could cause conflict. Two students said that the difficulty of the writing project was one of the challenges they faced. One expressed the view that the difficulty lies in "the topic of the project itself. Students may not have a clear background about that topic". Another student said that the issue was "the difficulty of the writing project and its complexity". In support of this, one of the teachers said that "Some students might not have the basic knowledge of the topics presented" and this may result in conflict among students when they approach their CW task. In order to avoid conflicts caused by students' lack of understanding of the writing task itself, teachers should give clear instructions about the task the students are expected to carry out (Hensvold, cited in Mutwarasibo, 2013). Further, teachers should help students understand the nature, purpose and learning outcomes of the given task (Griffiths, 2009).

Table 4. Some Strategies for Improving CW Practices

\begin{tabular}{llll}
\hline Questionnaire Item & M & SD & N \\
\hline 11.Good preparation for the writing task & 1.09 & .294 & 64 \\
12. Clear team work rules & 1.22 & .453 & 64 \\
13.Fair and clear division of the work among team members & 1.31 & .531 & 64 \\
14. Proper communication channels between team members & 1.35 & .572 & 64 \\
15.Decisions on how the team will be governed & 1.41 & .583 & 64 \\
\hline
\end{tabular}

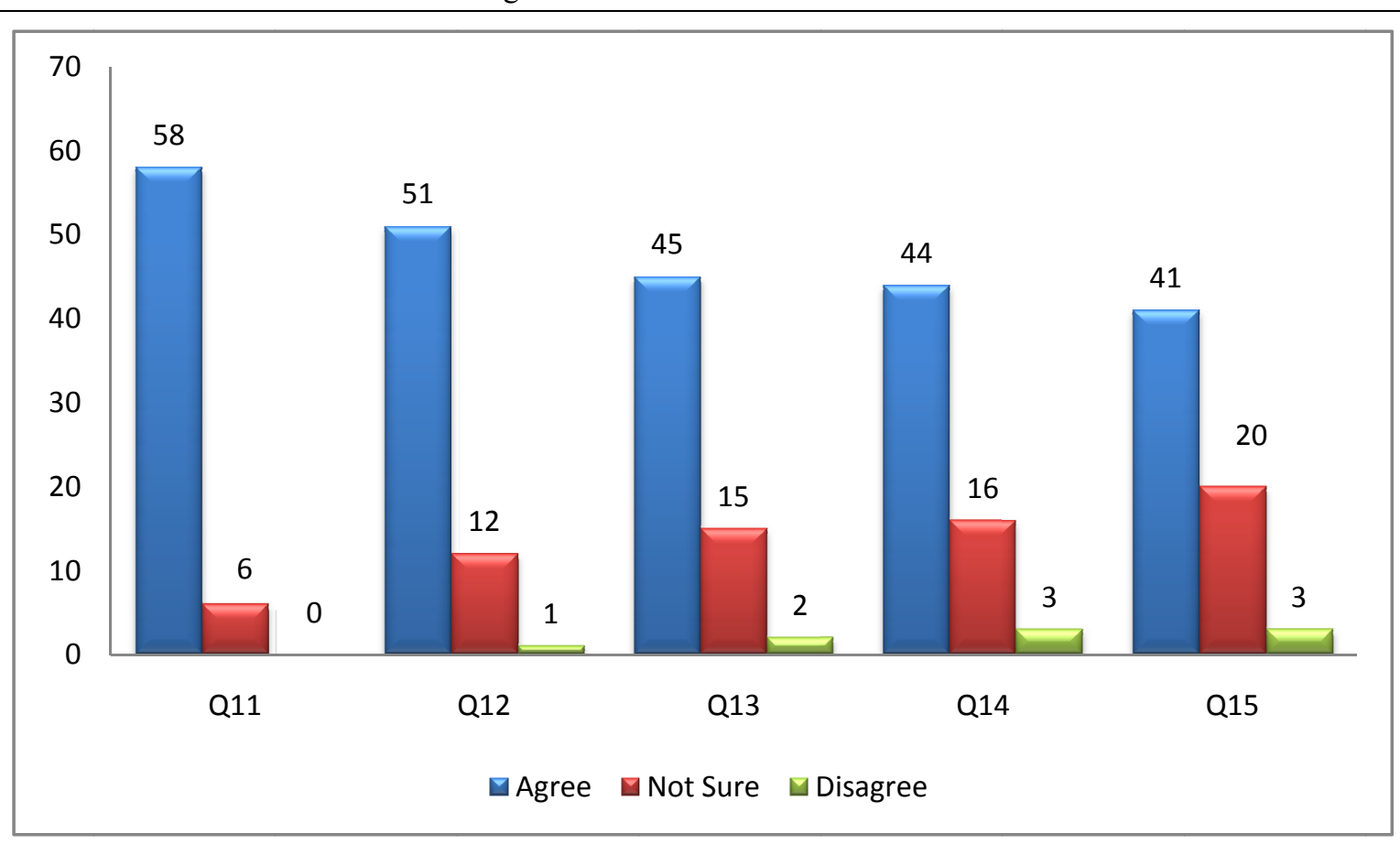

Figure 3. Students' views on how to make CW practice more effective 
Students' views on how they can make CW practice more effective are shown in Table 4 and Figure 3. Question 11, which emphasises good preparation for the writing task, resulted in the biggest number of students who agreed with the statement (58 students), while only six students disagreed. Question 12 was about setting clear team work rules and 51 students agreed, 12 were not sure and only one disagreed. In this regard, five students expressed the view that having a clear plan to follow is the key to success; as one of them put it, "each team should have a clear and effective plan for their projects". In support of this, Yang (2014) points out that group rules could facilitate the process of CW. In response to question 13, 45 students agreed with having a fair and clear division work among CW group members, while 15 were not sure and two disagreed. In fact, 30 students expressed this view in the qualitative data; for example, one of them suggested: "Divide the project between the members and everyone should submit it [their work] to the leader of group on time". The students are expected to practise mutual collaboration and share knowledge (Hammond et. al, 2010) and therefore all CW group members should divide the work among themselves and contribute to the writing process. Question 14 focuses on having proper communication among team members: 44 students agreed that this is effective, 16 were not sure and three disagreed. In fact, 12 students highlighted the difficulty of meeting with group members. One said that "some students are from different places, so they face difficulty in meeting and finishing the work". Another student attributed such difficulty to "conflicts of times between students". Regarding Question 15, 41 students agreed that decisions on how to govern the team can make $\mathrm{CW}$ effective, 20 were not sure, and three disagreed. Three students expressed their concern about bossy group members: one of them said that "some students like to force their opinions to do the projects in [a] certain way". Another student pointed out that "one member controls everything and does what he/she likes". A further student said: "one student controls the work and others are afraid of him/her". In this regard, one of the teachers said: "groups should be coherent and problems should be discussed and the reluctant members must be told that they would not get the same grade as the active ones"; another considered that "students should be appropriately 'grouped'.

Table 5. What could teachers do to help students with their CW tasks?

\begin{tabular}{llll}
\hline Questionnaire Item & M & SD & N \\
\hline 16. Workshops on how students can effectively work in CW groups & 1.42 & .662 & 64 \\
17. Continuous follow up of the different stages of the CW task & 1.27 & .445 & 64 \\
$\begin{array}{l}\text { 18. Seriously dealing with underproductive CW team members } \\
\text { 19. Clear assessment criteria which distinguishes hardworking students }\end{array}$ & 1.50 & .591 & 64 \\
$\quad \begin{array}{l}\text { from those who do not work hard in the CW task } \\
\text { 20. Meeting with the low achieving CW groups and giving them detailed } \\
\text { feedback on their work and advising them on how to do well next time }\end{array}$ & 1.29 & .665 & 64 \\
\hline
\end{tabular}

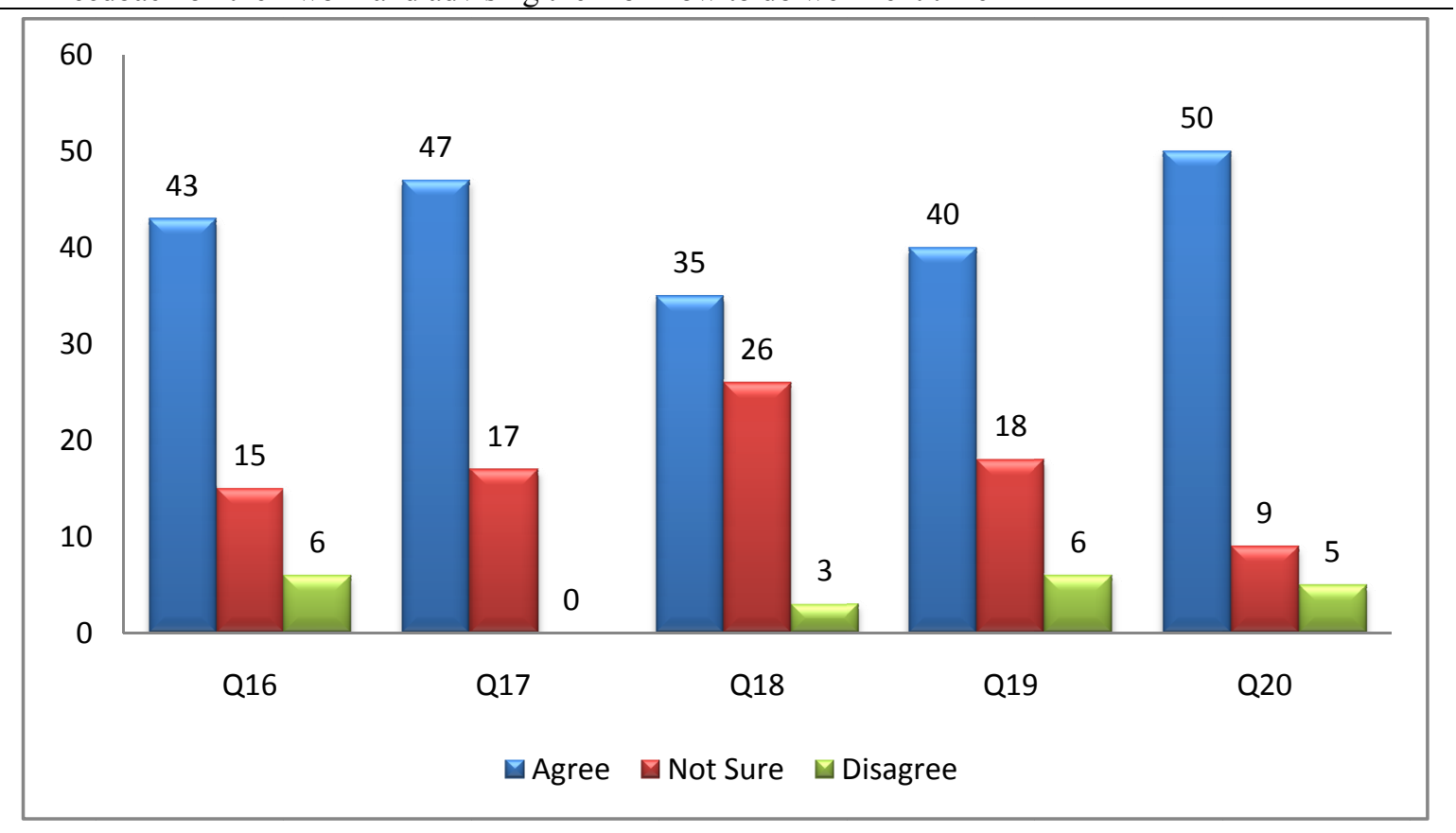

Figure 4. Students' views on how their teachers can help them improve CW practices 
Questions 16 to 20 were devoted to exploring students' views on how their teachers could help them with CW practice (see Table 5 and Figure 4). In fact, Pathinathan and Fung (2012) highlight the importance of teachers' awareness of student issues in their CW and stress that teachers should help them. For Question 16, 43 students agreed that teachers could help them by conducting workshops to train them on how to work effectively in CW groups, 15 were not sure while six disagreed. Forty-seven students agreed with the statement of Question 17 that teachers' continuous follow up would help them with their $\mathrm{CW}$ and 17 students were not sure. Four students expressed the view that teachers' feedback and monitoring are important. One said that they need to "get feedback from supervisor and experienced writers" and another student supported this by asking for "continuous monitoring". Further, a student pointed out that the "supervisor should be in touch with the groups to advise, comment and suggest possible and better opinions". One of the teachers supported this by saying "feedback should be obtained periodically during [the] task". Regarding Question 18, which is about taking serious action against passive CW group members, 35 students agreed with this, while, surprisingly, 26 students were not sure and three students disagreed. Actually, the vast majority of the students (22) expressed their unhappiness with the dependent and lazy CW group members. One said: "some students aren't working in team projects; they just depend on other members to complete the project". Another asserted that "some members don't take real responsibility on the project". A student also expressed the view that sometimes the work is done by one member: she pointed that, "they depend on one person to write the project". One of the teachers considered the existence of passive CW group members as one of the challenges of CW: "One big challenge is that one or two students can be passive and rely on the active peers' knowledge"; another teacher said: "Sometimes they complain about other members and that they do not work in a team manner".

According to Pathinathan and Fung (2012), teachers should encourage the passive students to take an active role in the CW task. Regarding Question 19, 40 students agreed that distinguishing hardworking students from those who do not work by having clear assessment criteria will make CW practice effective; but 18 students were not sure about this and six students disagreed. One student said that the "whole group gets the same mark at the end! So sleepers are not motivated to work". For this reason, six students called for the evaluation of students individually. One expressed the view that the "Teacher should give students the mark depending on each one's work", and another student supported this by saying that "if teachers give each student the real mark that represents his/her work, they will work better next time". Another student suggested punishment for those who do not work hard: "Students must be aware that they all have to work, otherwise they must be punished by having their marks reduced". In fact, Ali (2012, p. 157) highlights that "teachers should reconsider their assessment and mechanism approaches if [a] group-based approach is used so as to reward their students in a fair way based on what they have done". Regarding the final question (20), 50 students agreed that teachers' meeting with low achieving students in CW and giving advice would help, while nine students were not sure about this and five students disagreed. As there are many reasons behind having low achieving students in CW, Dobabo and Blum (2013, p. 375) underline the importance of "raising learners' awareness of the potential and actual benefits" of CW.

\section{Conclusions and Recommendations}

This study was conducted in order to explore teachers' and students' views about the use of CW, to investigate the problems the students face in CW, to explore the causes of the problems, and to elicit the teachers' and students' views on how to sustain CW practice in DELL. The study aimed to answer some research questions.

The results of this study revealed that the vast majority of EFL teachers and students support the use of CW in the context of the study. Yet, there are some challenges that students face such as having unproductive CW group members, conflicting opinions, and having bossy group members. The results of the study showed that the cause of the problems the students have in CW can be attributed to the CW group members' language proficiency level, their personality, their cultural background and their understanding of the assigned $\mathrm{CW}$ task itself.

The findings of this study could recommend that both teachers and students should strive to make CW tasks more effective in order to achieve quality in the written piece. For teachers, the study suggests that they should set clear $\mathrm{CW}$ tasks, provide students with clear instructions and guidelines, show clear learning outcomes for the $\mathrm{CW}$ tasks, train and guide students on how to work in $\mathrm{CW}$ groups, give students enough time to do their $\mathrm{CW}$, help solve students' conflicts and fairly assess students' CW. As far as students are concerned, they should be serious and committed to $\mathrm{CW}$, have good time and group management, plan how they will work on their $\mathrm{CW}$ clearly, establish rules for their $\mathrm{CW}$ team working, and fairly divide the $\mathrm{CW}$ work among themselves, and have a sense of mutual understanding. Teachers and students need to take all the above mentioned points into consideration in order to contribute to improving $\mathrm{CW}$ practice. 
One of the limitations of this study is the use of 3-point Likert Scale rather than 5 or 6-point which would enrich the data collected. Another limitation is in the sample of the study. Future research should therefore provide a wider overview of this issue by taking into account the views on $\mathrm{CW}$ by students and teachers from different departments and colleges and how to make improvements.

\section{References}

Aldosari, A. (2008). The influence of proficiency levels, task type and social relationships on pair interaction: An EFL context. Unpublished doctoral dissertation. University of Melbourne, Australia.

Alegri'a de la Colina, A., \& Garci'a Mayo, M. (2007). Attention to form across collaborative tasks by low-proficiency learners in an EFL setting. In M. Garci'a Mayo (ed.), investigating tasks in formal language learning (pp. 91-116). Clevedon, UK: Multilingual Matters.

Ali, H. (2012). Improving students' report writing quality in an EAP context: group versus individual. English Language Teaching, 5, 153-159. http://dx.doi.org/10.5539/elt.v5n3p153

Amirkhiz, S., Abu Bakar, K., Abd.Samad, A., Baki, R., \& Mahmoudi, L. (2013). EFL/ESL Learners' Language Related Episodes (LREs) during Performing Collaborative Writing Tasks. Journal of Language Teaching and Research, 4, 473-479. http://dx.doi.org/10.4304/jltr.4.3.473-479

Barnes, D. (1992). From communication to curriculum (2nd ed.). Portsmouth, NH: Heinemann.

Batstone, R. (ed.) (2010). Sociocognitive perspectives on language use and language learning. Oxford: Oxford University Press.

Biria, R., \& Jafari, S. (2013). The impact of collaborative writing on the writing fluency of Iranian EFL learners. Journal of Language Teaching and Research, 4, 164-175. http://dx.doi.org/10.4304/jltr.4.1.164-175

Bourner, J., Hughes, M., \& Bourner, T. (2001). First-year undergraduate experiences of group project work. Assessment \& Evaluation in Higher Education, 26(1), 19-39. http://dx.doi.org/10.1080/02602930020022264

Bruffee, K. A. (1986). Social construction, language and authority of knowledge: a biographical essay. College English, 48, 773-780. http://dx.doi.org/10.2307/376723

Bruffee, K. (1993). Collaborative learning: higher education, interdependence and the authority of knowledge. Baltimore, MD: Johns Hopkins University Press.

Bygate, M., Skehan, P., Swain, M. (eds.) (2001). Researching pedagogic tasks: Second Language Learning and Testing. Harlow, England: Pearson Education.

Cavanagh, M. (2011).Students' experiences of active engagement through cooperative learning activities in lectures. Active Learning in Higher Education, 12(1), 23-33. http:// dx.doi. org/ 10. 1177/ 1469787410387724

Daiute, C. (1986). Do 1 and 1 make 2? Patterns of influence by collaborative authors. Written Communication, 3 , 383-408. http://dx.doi.org/10.1177/0741088386003003006

Davies, W.M. (2009). Group work as a form of assessment: common problems and recommended solutions. Higher Education, 58(4), 563-584. http://dx.doi.org/10.1007/s10734-009-9216-y

De la Colina, A. A., Garc1'aMayo, M. P. G. (2007). Attention to form across collaborative tasks by low-proficiency learners in an EFL setting. In M. P. Garcia' Mayo (ed.), investigating tasks in formal language learning (pp.91-116). London, UK: Multilingual Matters.

Dobao, A. (2012). Collaborative writing tasks in the L2 classroom: comparing group, pair, and individual work. Journal of Second Language Writing, 21, 40-58. http:// dx.doi. org/10. 1016/ j.jslw .20 11.12.002

Dobao, A., Blum, A. (2013). Collaborative writing in pairs and small groups: learners' attitudes and perceptions. System, 41, 365-378. http://dx.doi.org/10.1016/j.system.2013.02.002

Donato, R. (1994). Collective scaffolding in second language learning. In J. P. Lantolf \& G. Appel (eds.), Vygotskian approaches to second language research (pp. 33-56). Norwood, NJ: Ablex.

Dörnyei, Z., Taguchi, T.(2010).Questionnaires in second language research: construction, administration, and processing. New York: Routledge.

Ellis, R. (2003). Task-based language learning and Teaching. Oxford: Oxford University Press.

Elola, I., Oskoz, A. (2010). Collaborative writing: fostering foreign language and writing conventions development. Language Learning \& Technology, 14, 51-71. 
Emig, J. (1977). Writing as a mode of learning.College Composition and Communication, $28,122-128$. http://dx.doi.org/10.2307/356095

Ewald, J. (2005). Language-related episodes in an assessment context: a 'small-group quiz'. The Canadian Modern Language Review, 61, 565-586. http://dx.doi.org/10.3138/cmlr.61.4.565

Fawcett, L.M., \& Garton, A.F. (2005).The effect of peer collaboration on children's problem-solving ability. British Journal of Educational Psychology, 75, 157-169. http://dx.doi.org/10.1348/000709904X23411

Fung, Y. M. (2006). The nature and dynamics of collaborative writing in Malaysian tertiary ESL setting. Unpublished doctoral dissertation. Massey University, Palmerston North, New Zealand.

Fung, Y. (2010). Collaborative writing features. RELC Journal, 41, 18-30. http://dx.doi:10.1177/0033688210362610

Garcıa Mayo, M. (ed.) (2007). Investigating tasks in formal language learning.Clevedon, UK: Multilingual Matters.

Gillies, R.M. (2008).Teachers' and students' verbal behaviours during cooperative learning. In R.M. Gillies, A. Ashman,\& J. Terwel (eds.), The teacher's role in implementing cooperative learning in the classroom (pp. 243-262). Brisbane: Springer. http://dx.doi.org/10.1007/978-0-387-70892-8_12

Granström, K. (2006). Group phenomena and classroom management in Sweden.In C.M. Evertson, C.S. Weinstein (eds.), Handbook of classroom management: Research, practice and contemporary issues (pp. 1141-1160). Mahwah: Lawrence Erlbaum Associates.

Griffiths, S. (2009). Teaching and learning in small groups. In H. Fry, S. Ketteridge, S. Marshall (eds.), $A$ handbook for teaching and learning in higher education: Enhancing academic practice (3rd ed., pp. 72-84).New York and London: Routledge.

HammarChiriac, E. (2011) Research on group work in education. New York: Nova Science Publishers.

Hammond, J.A., Bithell, C.P., Jones, L., Bidgood, P. (2010). A first year experience of student-directed peer-assisted learning. Active Learning in Higher Education, 11(3), 201-212. http://dx.doi.org/10.1177/1469787410379683

Herrington, A. J. (1981). Writing to learn: writing across the disciplines. College English, 43, $379-387$. http://dx.doi.org/10.2307/377126

Hillyard, C., Gillespie, D., Littig, P. (2010). University students' attitudes about learning in small groups after frequent participation.Active Learning in Higher Education, 11(1), 9-20. http://dx.doi.org/10.1177/1469787409355867

Hirvela, A. (2011). Writing to learn in content areas: research insights. In R. Mancho'n (ed.), Learning-to-write and writing-to-learn in an additional language (pp. 159-180). Amsterdam: John Benjamins. http://dx.doi.org/10.1075/1llt.31.06hir

Hyland, K. (2011). Learning to write: issues in theory, research, and pedagogy. In R. Mancho'n (Ed.), Learning-to-write and writing-to-learn in an additional language (pp. 18-35). Amsterdam: John Benjamins. http://dx.doi.org/10.1075/1llt.31.05hyl

Johnson, D.W., Johnson, R.T., Smith, K. (2007). The state of cooperative learning in post-secondary and professional settings. Educational Psychology Review, 19, 15-29. http:// dx.doi. org/10. 1007/ s106 48-006-9038-8

Kim, Y. (2008). The contribution of collaborative and individual tasks to the acquisition of L2 vocabulary. The Modern Language Journal, 92(1), 114-130. http://dx.doi.org/10.1111/j.1540-4781.2008.00690.x

Kim, Y. J., McDonough, K. (2008). The effect of interlocutor proficiency on the collaborative dialogue between Korean as a second language learner. Language Teaching Research, 12, 211-234. http://dx.doi.org/10.1177/1362168807086288

Kuiken, F., Vedder, I. (2002a). The effect of interaction in acquiring the grammar of a second language. International Journal of Educational Research, 37(3-4), 343-358. http://dx.doi.org/10.1016/S0883-0355(03)00009-0

Kuiken, F., Vedder, I. (2002b). Collaborative writing in L2: The effect of group interaction on text quality. In S. Ransdell, M. Barbier (eds.), New directions for research in L2 writing (pp. 169-188). Dordrecht: Kluwer. http://dx.doi.org/10.1007/978-94-010-0363-6_9

Lantolf, J. (ed.) (2000). Sociocultural theory and second language learning. Oxford: Oxford University Press.

Leach, L., Zepke, N. (2011). Engaging students in learning: a review of a conceptual organiser. Higher Education Research \& Development, 30(2), 193-204. http:// dx.doi. org/ 10. 1080/ 07294360.2010 .509761 
Leeser, M. J. (2004). Learner proficiency and focus on form during collaborative dialogue. Language Teaching Research, 8, 55-81. http://dx.doi.org/10.1191/1362168804lr134oa

Li, M., Zhu, W. (2013). Patterns of computer-mediated interaction in small writing groups using wikis. Computer Assisted Language Learning, 26, 61-82. http:// dx.doi. org/10. 1080/ 09588 221. 2011.631142

Lightbown, P. M., Spada, N. (2006). How languages are learned (3rd. ed.). Oxford: Oxford University Press.

Lockhart, C., Ng, P. (1995). Analysing talk in ESL peer response groups: stances, functions, and content. Language Learning, 45, 605-651. http://dx.doi.org/10.1111/j.1467-1770.1995.tb00456.x

Mancho'n, R. (2011). Writing to learn the language: issues in theory and research. In R. Mancho'n (Ed.), Learning-to-write and writing-to-learn in an additional language (pp. 61-84). Amsterdam: John Benjamins. http://dx.doi.org/10.1075/1llt.31.07man

McDonough, K. (2004). Learner-learner interaction during pair and small group activities in a Thai EFL context. System, 32, 207-224.http://dx.doi.org/10.1016/j.system.2004.01.003

McDonough, K., Sunitham, W. (2009). Collaborative dialogues between Thai EFL learners during self-access computer activities. TESOL Quarterly 43, 231-254.Millis, B.J., Cottell, P.G. (1998).Cooperative learning for higher education faculty. Phoenix: Oryx Press.

Millis, B.\& Cottel, P. (1998).Cooperative learning for higher education faculty. Phoenix: Oryx Press.

Mutwarasibo, F. (2013).University students' conceptions and practice of collaborative work on writing. International Journal of Higher Education, 2, 13-21. http://dx.doi.org/10.5430/ijhe.v2n2p13

Nassaji, H., Tian, J. (2010). Collaborative and individual output tasks and their effects on learning English phrasal verbs. Language Teaching Research, 14, 397-419. http:// dx.doi.org/ 10.1177/ 1362168810375364

Nelson, G. L., Murphy, J. M. (1992). An L2 writing group: task and social dimensions. Journal of Second Language Writing, 1, 171-193. http://dx.doi.org/10.1016/1060-3743(92)90002-7

Newell, G. F. (1998). 'How much are we the wiser?' Continuity and change in writing and learning in the content areas. In N. Nelson, R. C. Calfee (eds.), The reading-writing connection: ninety-seventh yearbook of the national society for the study of education, Part II, (pp. 178-202). Chicago IL: University of Chicago Press.

Pathinathan, S., Fung, Y. (2012).Intragroup conflicts during collaborative writing in an ESL/ EFL preparatory programme. International Journal of Applied Linguistics \& English Literature, 1, 8-18. http://dx.doi.org/10.7575/ijalel.v.1n.7p.8

Race, P. (2010).Making learning happen: A guide for post-compulsory education (2nd ed.). London: Sage. Shehadeh, A. (2011).Effects and student perceptions of collaborative writing in L2. Journal of Second Language Writing, 20, 286-305. http://dx.doi.org/10.1016/j.jslw.2011.05.010

Razmjoo, S., Hoomanfard, M. (2012).On the effect of cooperative writing on students' writing ability, WTC, self-efficacy, and apprehension. World Journal of English Language, 2, 19-28. http://dx.doi.org/10.5430/wjel.v2n2p19

Shehadeh, A. (2011). Effects and student perceptions of collaborative writing in L2. Journal of Second Language Writing, 20, 286-305. http://dx.doi.org/10.1016/j.jslw.2011.05.010

Shehadeh, A., Coombe, C. (eds.) (2010). Applications of task-based learning in TESOL. Alexandria, VA: TESOL.

Shimazoe, J., Aldrich, H. (2010). Group work can be gratifying: Understanding and overcoming resistance to cooperative learning. College Teaching, 58, 52-57. http://dx.doi.org/ 10.1080/ 87567550903418594

Storch, N. (1997). The editing talk of adult ESL learners. Language Awareness, 6, 221-232. http://dx.doi.org/10.1080/09658416.1997.9959931

Storch, N. (2002). Patterns of interaction in ESL pair work. Language Learning, 52, 119-158. http://dx.doi.org/10.1111/1467-9922.00179

Storch, N. (2005). Collaborative writing: product, process, and students' reflections. Journal of Second Language Writing, 14(3), 153-173.http://dx.doi.org/10.1016/j.jslw.2005.05.002

Storch, N. (2011). Collaborative writing in L2 contexts: processes, outcomes, and future directions. Annual Review of Applied Linguistics, 31, 275-288. http://dx.doi.org/10.1017/S0267190511000079

Storch, N., Wigglesworth, G. (2007). Writing tasks: the effects of collaboration. In M. Garcia Mayo (ed.), Investigating tasks in formal language learning (pp. 157-177). Clevedon, UK: Multilingual Matters. 
Swain, M. (1998). Focus on form through conscious reflection. In: Doughty, C., Williams, J. (eds.), Focus on Form in Classroom Second Language Acquisition. Cambridge University Press, Cambridge, pp. 64e81.

Swain, M. (2000). The output hypothesis and beyond: Mediating acquisition through collaborative dialogue. In J. Lantolf (ed.), Sociocultural theory and second language learning (pp. 97-114). Oxford: Oxford University Press.

Swain, M. (2001). Integrating language and content teaching through collaborative tasks. Canadian Modern Language Review, 58, 44-63.http://dx.doi.org/10.3138/cmlr.58.1.44

Swain, M. (2006). Languaging, agency and collaboration in advanced second language learning. In H. Byrnes (ed.), Advanced language learning: the contributions of Halliday and Vygotsky (pp. 95-108). London: Continuum.

Swain, M. (2010). 'Talking-it-through': Languaging as a source of learning. In R. Batstone (ed.), Sociocognitive perspectives on language use and language learning (pp. 112-130). Oxford: Oxford University Press.

Swain, M., Lapkin, S. (1998). Interaction and second language learning: two adolescent French immersion students working together. The Modern Language Journal, 320-337.http://dx.doi.org/10.1111/j.1540-4781.1998.tb01209.x

Swain, M., Lapkin, S. (2001). Focus on form through collaborative dialogue: exploring task effects. In M. Bygate, P. Skehan, M. Swain (eds.), Researching pedagogic tasks: second language learning, teaching and testing (pp. 99-118). London: Longman.

Swain, M., Lapkin, S. (2002).Talking it through: two French immersion learners' response to reformulation. International Journal of Educational Research, 37, 285-304.http://dx.doi.org/10.1016/S0883-0355(03)00006-5

Swain, M., Lapkin, S., Knouzi, I., Suzuki, W., Brooks, L. (2009).Languaging: university students learn the grammatical concept of voice in French. The Modern Language Journal, 93, 5-29.http://dx.doi.org/10.1111/j.1540-4781.2009.00825.x

Van den Branden, K., Bygate, M., Norris, J. (eds.) (2009).Task-based language teaching: A reader. Amsterdam: John Benjamin's.

Vygotsky, L. (1978). Mind in society: the development of higher psychological processes. Cambridge, MA: Harvard University Press.

Watanabe, Y., Swain, M. (2007). Effects of proficiency differences and patterns of pair interaction on second language learning: collaborative dialogue between adult ESL learners. Language Teaching Research, 11,121-142.http://dx.doi.org/10.1177/136216880607074599

Wells, G. (1999). Dialogic inquiry: Toward a sociocultural practice and theory of education. Cambridge: CUP. http://dx.doi.org/10.1017/CBO9780511605895

Wigglesworth, G., Storch, N. (2009). Pairs versus individual writing: effects on fluency, complexity and accuracy. Language Testing, 26, 445-466.http://dx.doi.org/10.1177/0265532209104670

Wigglesworth, G., Storch, N. (2012). What role for collaboration in writing and writing feedback? Journal of Second Language Writing, 21, 364-374. http://dx.doi.org/10.1016/j.jslw.2012.09.005

Williams, J. (1999). Learners' Generated Attention to Form. Language Learning, 49, 583-625. http://dx.doi.org/10.1111/0023-8333.00103

Williams, J. (2001). The effectiveness of spontaneous attention to form. System, 29, 325-340. http://dx.doi.org/10.1016/S0346-251X(01)00022-7

Williams, J. (2012). The potential role (s) of writing in second language development. Journal of Second Language Writing, 21, 321-331.http://dx.doi.org/10.1016/j.jslw.2012.09.007

Wingate, U., Andon, N., Cogo, A. (2011). Embedding academic writing instruction into subject teaching: a case study. Active Learning in Higher Education, 12, 69-81. http://dx.doi.org/10.1177/1469787410387814

Yang, L. (2014).Examining mediational means in collaborative writing: case studies of undergraduate ESL students in business courses. Journal of Second Language Writing, 23, 74-89. http://dx.doi.org/10.1016/j.jslw.2014.01.003

Yockey, R. D. (2011). SPSS demystified: a step-by-step guide to successful data analysis. Boston: Longman.

Zeng, G., Takatsuka, S. (2009). Text-based peer-peer collaborative dialogue in a computer-mediated learning environment in the EFL context. System 37, 434-446. http://dx.doi.org/10.1016/j.system. 2009.01.003 


\section{Appendix A: Quantitative Data}

A summary of the main themes elicited from the quantitative data.

Q 21. In your opinion, what are the other possible challenges that face students in $\mathrm{CW}$ tasks?

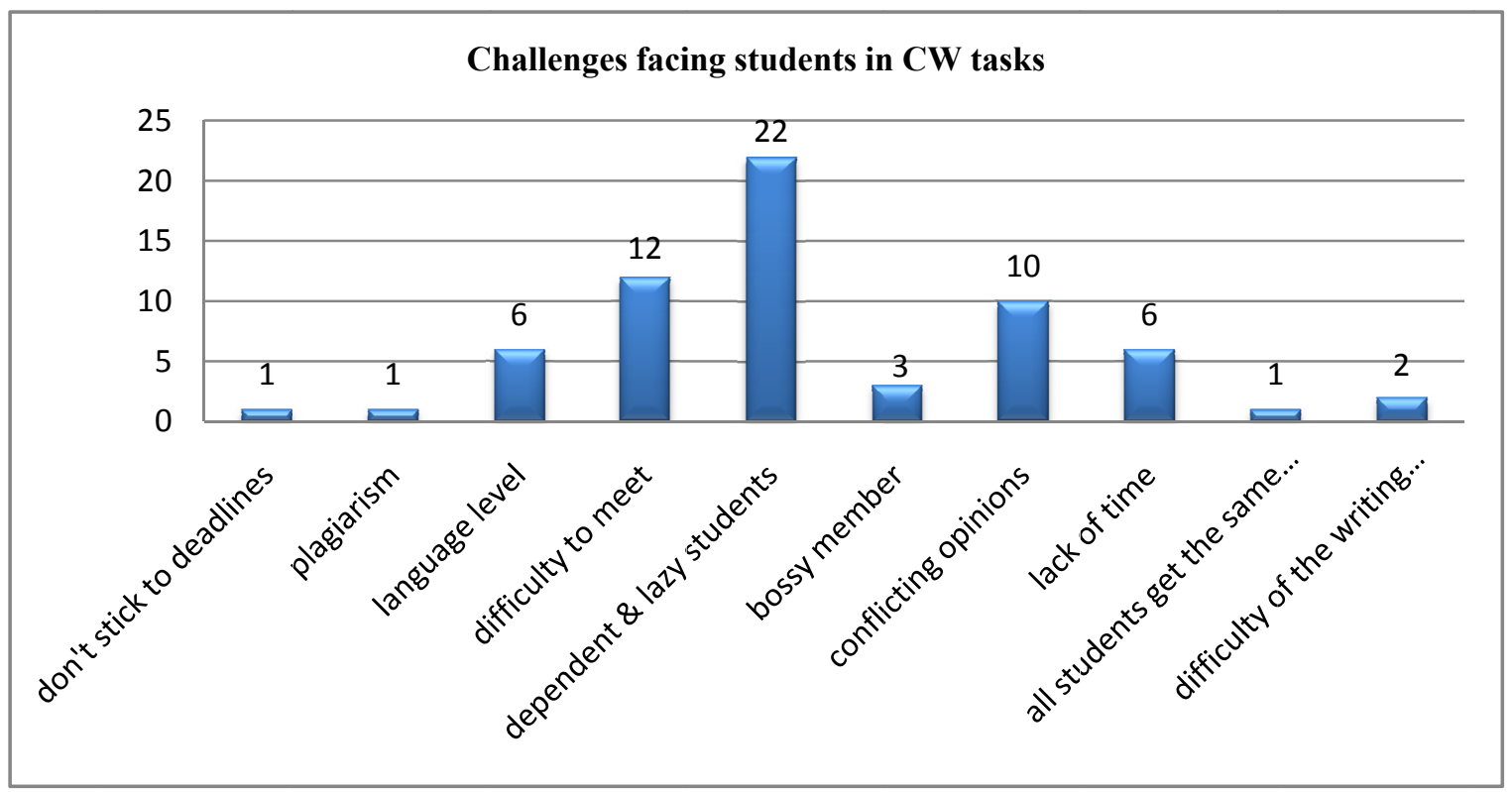

Q 22. In your opinion, how can $\mathrm{CW}$ tasks be improved?

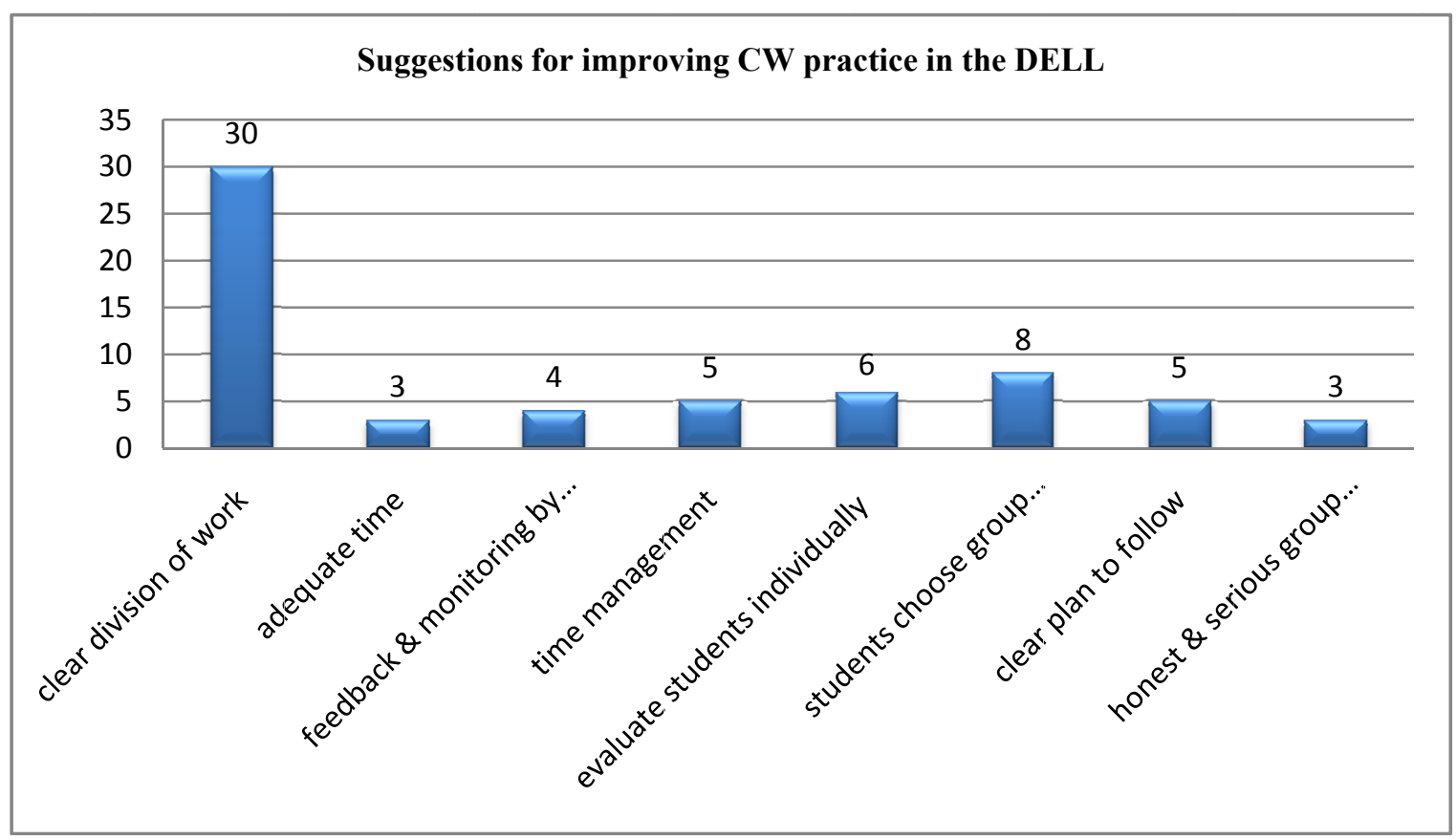




\section{Appendix B: Qualitative Data:}

A summary of the main themes elicited from qualitative the data.

Question 1: Do you support the idea of using collaborative writing in collaborative assignments? Why or why not?

T1: at the beginning, writing could be done collaboratively since students can exchange ideas while passing through writing stages. Gathering ideas could be best done through group brainstorming.

T2: I do strongly support collaborative activities in writing classes as well as giving collaborative assignments because each of the students can bring useful input into the assignment, that is they can peer teach and easily achieve fruitful results/ outcome.

T3: Yes, because learners can share their knowledge and learn from each other and fill the gaps in each other's knowledge.

T4: I support this. Students can learn from their peers. Students can be motivated to complete tasks. Learning is enhanced as the students inclined to be collaborating in a relaxed environment.

T5: Yes. This is to encourage students to share their "creative juices" in a fun way. This also encourage group work and the possibility of coming up with diverse ideas into just one output. Students doing collaborative assignment need to brainstorm as a group \& this implies that the idea of autonomous learning is encouraged.

Question 2: What are the challenges that your students usually face in collaborative writing?

T1: Students might not agree about sub-ideas of the topics that will lead them not to take part in the writing process. Some students might not have the basic knowledge of the topics presented.

T2: One big challenge is that one or two students can be passive and rely on the active peers' knowledge (this is common in big group activities).

T3: Sometimes they complain about other members and that they do not work in a team manner.

T4: Weaker students tend to be at the mercy of stronger students and remain in the shadows.

T5: I haven't used this strategy in my classes for the past few years, but way back students did explain of different attitudes of group members. Some have tendency to put in more efforts than others.

Question 3: In your opinion, why do some students dislike collaborative writing and collaborative assignments?

T1: If we agree or not the writing skill is the most difficult. Every student likes to show how creative he is. Other students don't like to be responsible for errors committed by an individual.

T2: Writing is a controlled practice, and some students have difficulty and can be under the pressure of the assignment. Those students who have difficulty in thinking effectively (analytic reasoning) defect collaborative writing: they do not want to show these weaknesses.

T3: In fact not all of them. Sometimes they prefer to work collaboratively than individually. I think problems occur when the group is not coherent, and when some members do not do their job appropriately.

T4: Some students have a high input and are by nature more active learners. They dislike doing all the work. Some students do not get to reveal their strengths or weaknesses.

T5: Perhaps the students want to own their own writing-this way they can call it truly theirs. Putting in ideas of others may/ can call confusion-"too many could avail the both" or so the saying goes.

Question 4: How can collaborative writing be promoted?

T1: I think students can work in groups in the first and the second stages. Having discussed the main ideas and prepare clusters. Students should work individually to show their own ideas and details.

T2: By using constructive approach to teaching.

T3: Groups should be coherent and problems should be discussed and the reluctant members must be told that they would not get the same grade as the active ones.

T4: Students should be appropriately 'grouped'. Feedback should be obtained periodically during task. Feedback must be obtained from each student post assignment.

T5: Collaborative writing may be provided \& integrated to institutions that contain a good English departments which are ready for creative writing programs / centres. 